\title{
IN VITRO PROPAGATION AND GRAFTING TECHNOLOGY PROMOTE ROOT INITIATION, SHOOT PROLIFERATION AND GRAFTING OPERATION OF VOLKAMER LEMON CITRUS ROOTSTOCK (Citrus volkameriana Ten. ) \\ Samaan, L. G. 1; M.S.S. EL-Boraey'; E.F. A.EL-Dengawy ${ }^{2}$ and Mona E. M. Helal ${ }^{1}$ \\ 1- Department of Pomology, Faculty of Agric., Mansoura Univ., Egypt \\ 2- Department of Pomology, Faculty of Agric., Damitta branch, Mansoura Univ., Egypt
}

\begin{abstract}
The in vitro response of shoot tip and epicotyl explants from Volkamer lemon Citrus rootstock (Citrus volkameriana Ten) coupled with shoot tip micro-grafting were observed for the first time. Further analysis was performed to verify the in vitro shoots and roots proliferation in these explants under different treatments. It were observed there different patterns of morphogenic shoots and roots gradient between the two tested explants noticed. These different patterns were influenced by factors related to explants type and the composition of the culture medium either for shoots or roots proliferation. The epicotyls could be used as source of explants for micro-propagation of Volkamer lemon to improve the efficiency of shoots and roots production with higher qualities.

Culturing medium to in vitro best shoot proliferation was MS (1962) basal medium at full strength supplemented with BAP at $1.5 \mathrm{mg} / \mathrm{L}$ and $\mathrm{Kin}$ at $1.00 \mathrm{mg} / \mathrm{L}$ plus a fixed $0.50 \mathrm{mg} \mathrm{NAA} / \mathrm{L}$. The statistical analysis technique used to indicate the effect of each growth regulator applied either solely or in combinations confirmed the superiority of BAP during proliferation stage as the limited factor affecting proliferated shoot characteristics on both explants type. Medium to best in vitro rooting was that of the same basal medium containing IBA and NAA at $2.00 \mathrm{mg} / \mathrm{L}$ each plus a fixed 0.50 $\mathrm{mg} \mathrm{Kin/L.}$

Micro-grafting study of Washington navel and Valencia scions onto Volkamer lemon rootstock through the measurements of three parameters, are known to be good measures for evaluating the graft compatibility between the two partners, obviously cleared that Valencia scion onto this rootstock is more compatible than Washington navel scion onto the same rootstock.
\end{abstract}

\section{INTRODUCTION}

The economic importance of the genus Citrus and the potential for further improvement via genetic manipulation, in vitro regeneration has been the subject of research for many years. Using this technique also is preferred because it ensures true to type plants, uniform quality, regular bearing, etc. Tissue culture techniques particularly micro-propagation using explant tissues, cells and protoplasts are now feasible and has been described in several species using stem and epicotyl segments ( Edress \& Burger, 1984; Sim et al., 1989; Goh et al., 1995; Maggon \& Singh, 1995; Ghorbel et al., 1998 ; Bordon et al., 2000 and Moreira-Das et al., 2000). Consequently, they are now gaining popularity among nurserymen due to the many advantages over conventional methods of vegetative propagation in particular to resolve the major constraint for Citrus rapid adoption by local growers that is the limited availability of elite germplasm pathogen free. This beside obtaining a 
large number of genetically identical, physiologically uniform and developmentally normal plantlets in a reduced time period and at a lowered cost. A single explant can be multiplied into several thousands plants in less than one year (Matsumoto et al., 2000; Singh, 2002 and Lineberger, 2006). Nowadays, there is no modern nursery, institute or laboratory working in the field of basic or applied research does not make ample use of this technology.

The ability of Citrus tissue culture regenerators to grow on different rootstocks was previously investigated using a technique based on the existence of in vitro and in vivo micro-grafting method (Murashige, et al., 1972; Navarro, et al.,1975; Edriss \& Burger, 1984; and Tusa, et al., 1988). The technique termed shoot tip micro-grafting can be bypasses viruses in infected trees. Moreover, this procedure permits horticulturists to go back to the best old line trees that could not propagated conventionally because they have became virus infected but which still have desirable fruits or other uses. Ke et al. (1993) also proved that micro-grafting was succeeded to shorten the time required for transfer of in vitro derived plants to field. The two most important lessons learned from these trails are that this methodology is a mean of accelerating asexual propagation and the produced plants by these techniques respond similarity any to one-rooted vegetative propagated plant.

The objective of the current study was to investigate factors affecting optimal conditions for shoot multiplication from 2 explant types of volkamer lemon citrus rootstock and on subsequent rooting of in vitro regenerated shoots. The design of this investigation also involved a composition Washington navel and Valencia arranges as scions and the indicated above rootstock to determine the requirements for establishment, successful goals combinations and transplanting.

\section{MATERIALS AND METHODS}

The present research was carried out during three successive years from 2004 to 2007 in order to study the possibility of using tissue culture technique for rapid multiplication and economical value in vitro micropropagation of Volkamer lemon Citrus rootstock (Citrus volkameriana Ten.). Factors considered in this investigation were explants tissue and optimum medium to obtain best root and shoot proliferation.

Explants: Two explants type were tested in this study, the first one was actively shoot tips $2 \mathrm{~cm}$ in length each such explants were collected from in vitro newly growing shoots previously resulted in vitro cultured seeds of the rootstock in glass jars $(12 \times 6 \mathrm{Cm})$, each 7 seeds were shown each at the tissue culture laboratory of the Horticulture Department, Agriculture Faculty, The University of Mansoura using MS (1962) at full strength and hormonefree as a culture medium. After leaf removal, shoots were surface disinfested for $15 \mathrm{~min}$ in a continuously stirred $1 \%$ Clorox solution containing $0.1 \%$ Tween $20(\mathrm{v} / \mathrm{v})$ as spreading agent and the terminal parts were separated 1.0 $\mathrm{Cm}$ in length each using scalpel blade and forceps, in sterile Petri dishes under aseptic condition. As for the second type, they were epicotyl explants prepared from the germinated seeds. The separated explants were surface 
sterilized in a laminar flow hood by immersing them into $70 \%$ ethanol solution for one minute, followed by dipping in $47.7 \%$ sodium hypo-chloride ( $\mathrm{NaOCL}$ ) for $10 \mathrm{~min}$, then rinsed three times in sterile distilled water and transferred to culture glass jars $(9 \times 5.5 \mathrm{Cm})$ containing basal medium in complete formation. Medium: The culture medium for in vitro shoot proliferation was consisted of Murashige and Skoog inorganic salts and vitamins at full strength as the basal medium (DeCleene \& Ley, 1976) containing $30 \mathrm{~g} / \mathrm{L}$ sucrose as carbon and energy source and pure Difco Bacto- agar at the rate of $7 \mathrm{mg} / \mathrm{L}$ for medium solidification. Such medium also was supplemented with 6benzylaminopurine (BAP) at $0.00,0.25,0.50,0.75,1.50$ and $1.50 \mathrm{mg} / \mathrm{L}$ and 6 furfurylaminopurine (Kin) at $0.25,0.50,0.75$ and $1.00 \mathrm{mg} / \mathrm{L}$ applied either solely or in combinations plus a-naphthalene acetic acid (NAA) at a fixed $0.50 \mathrm{mg} / \mathrm{L}$. The culture medium for root proliferation was consisted of the same MS basal medium combined with 2 auxins, Indole-3-butyric acid (IBA) at $0.50,1.00,1.50$ and $2.00 \mathrm{mg} / \mathrm{L}$ and NAA at $0.50,1.00,1.50$ and $2.00 \mathrm{mg} / \mathrm{L}$ added either solely or in combinations at $0.50,1.00,1.50$ and $2.00 \mathrm{mg} / \mathrm{L}$ each plus a fixed $0.50 \mathrm{mg} \mathrm{Kin/L}$. The $\mathrm{pH}$ of shoot proliferation media was adjusted to 5.8 before the addition of agar. Media were dispensed into $9 \times 5.5 \mathrm{Cm}$ glass jars by each contained $30 \mathrm{ml}$ of nutrient media. The cultured jars covered with polypropylene sheets were held in place rubber bands that resistance of higher hot degree through autoclaved at $121 \mathrm{C}^{\circ}\left(1.2 \mathrm{~kg} / \mathrm{Cm}^{3}\right)$ for $20 \mathrm{~min}$, then left to cool and harden for $24 \mathrm{hr}$ before being used.

Culture procedure for shoot proliferation: Explants were cultured individually in glass jars $(9 \times 5.5 \mathrm{Cm})$ each contained $30 \mathrm{ml}$ of tested shoot proliferation media and were placed in growth culture room at $25 \pm 2 \mathrm{C}^{\circ}$ under fluorescent light receiving $16 \mathrm{hr}$ illumination followed by $8 \mathrm{hr}$ dark period. Four weeks later culturing date, shoot multiplication percentage and average shoots number, average leaves number along with average shoot length per explant were measured on the proliferated shoots on each explant used. The former shoot characteristic was calculated according to the following equation:

$$
\text { Shoot multiplication\%= -- Number of cultured explants }
$$

Proliferated shoots were used as a mother stock for the subsequent rooting experiments.

Statistical analysis: Shoot proliferation experiment were designed as 42 treatments, ten replicates one explants each followed the method described by Mass, et al. (1994).

Root proliferation on cuttings: The concerned experiment was designed to examine the efficiency of the tested rooting media in promoting adventitious root formation on cuttings prepared from the regenerated shoots on both explant types and in turn or determine best in vitro rooting media. These cuttings were taken from uniformity growing regenerated shoots derived from shoot proliferation experiments. The culture media were MS(1962)basal medium at full strength supplemented with IBA and NAA at the concentrations indicated above applied either solely or in combinations plus a 
fixed $0.50 \mathrm{mg} \mathrm{Kin} / \mathrm{L}$. Sucrose at $30 \mathrm{mg} / \mathrm{L}$ and Difco Bacto- agar at $7 \mathrm{mg} / \mathrm{L}$ were also added. $\mathrm{Ph}$ of the rooting media was adjusted to 5.7 before addition of agar and dispensed in glass jars $(9 \times 4.5 \mathrm{Cm}), 30 \mathrm{ml}$ each. The cultured jars were closed with plastic covers of high temperature resistant, autoclaved at $121 \mathrm{C}^{\circ}$ for $20 \mathrm{~min}$ and left to cool and harden for two days before being used. Micro-cuttings were carefully excised at $1.0 \mathrm{Cm}$ in length (rooting explants) from regenerated shoots by removing basal nature leaves and forceps were used, pre-using they were soaked into $70 \%$ ethanol and flame treated. Cuttings were individually inserted vertically into jars containing $30 \mathrm{ml}$ of rooting media tested and incubated on racks in growth culture room at $25 \pm 2 \mathrm{C}^{\circ}$ under $16 \mathrm{hr}$ photoperiod of high light intensity ( $1500 \mathrm{Lux}$ ) provided by white fluorescent light followed by $8 \mathrm{hr}$ dark period. Six weeks later culturing date, roots number, root length and average root diameter per cutting were measured.

Statistical analysis: Root proliferation experiment was set up in completely randomized design. Eight treatments were consisted of ten replicates one cultured jar each. Data were analyzed by analysis of variance with LSD value at $5 \%$ level of probability according to the procedure explained by Pontikis and Sapoutzaki (1985).

Micro-grafting experiment: Micro-grafting operations of Washington navel and Valencia scions to in vitro seedlings of Volkamer lemon rootstock were carried out to calculate grafting success \% and evaluate the degree of scionrootstock compatibility.

Rootstock in this study was seedlings resulted from previously in vitro cultured seeds of Volkamer lemon (cultured in glass tubes 2 seeds each) after off- type ones were eliminated. The source of scions was apical portion of new growing shoots of both orange cultivars. As for micro-grafting procedure, the rootstock seedlings were taken out individually from the cultured tubes to a sterile Petri dish lined with sterile moist Whitman No. 50 filter paper to retard desiccation of tissues during excision and grafting. Rootstock epicotyls were decapitated to $1-2 \mathrm{Cm}$ each and subjected to make an inverted T incision through the cortex to the cambial region. A thin film of the solid germination medium was put on the incision before the insertion of the soaked apical tips (scions) into the incision. The grafted seedlings were transferred individually and carefully to special cultured glass tubes (150x25 $\mathrm{mm}$ ) each containing $15 \mathrm{ml}$ culture medium of $\mathrm{MS}$ basal medium supplemented with $1 \mathrm{ml} / \mathrm{L}$ thiamine-HCL, $1 \mathrm{mg} / \mathrm{L}$ pyridoxine- $\mathrm{HCL}, 1 \mathrm{mg} / \mathrm{L}$ nicotinic acid, $2 \mathrm{mg} / \mathrm{L}$ glucose, $5 \mathrm{mg} / \mathrm{L}$ calcium pentathenate and $100 \mathrm{mg} / \mathrm{L}$ myo-inositol. The cultured tubes were placed on the bridge, covered with aluminum foil and kept upright in the incubator at $25 \pm 2 \mathrm{C}^{\circ}$ for 4 days, in the dark for 2 weeks and finally transferred to light intensity of 1500 Lux for 4 weeks.

Acclimatization of micro-grafted plantlets was done by carefully taken them out from the glass tubes, thoroughly washed with sterile distilled water at $30 \mathrm{C}^{\circ}$ to remove any carryout of the medium to eliminate contamination which may occur around the roots and then transplanted to culture growing pots containing a mixture of peat moss, vermiculite, perlite and sand (1:1:1:1 
$\mathrm{v} / \mathrm{v})$. The culture growing medium before culturing were autoclaved at $121 \mathrm{C}^{\circ}$ $(1.5 \mathrm{~kg} / \mathrm{Cm})$ for $20 \mathrm{~min}$. The cultured pots were transferred to glass box ( 100 x $60 \times 25 \mathrm{Cm}$ ) covered with white sheet of polyethylene for two weeks in the laboratory in order to keep the grafted plantlets at a high relative humidity. Water plus Hogland nutritional solution were added to the bottom of the box at $0.50 \mathrm{Cm}$ in hight. One week later, they were transferred to grow under the greenhouse conditions.

Scion-rootstock compatibility: This was estimated basing on the measurement of three main parameters on the grafted plantlets, average grafting success \% at one- month- old; grafts in vitro (micro-grafting operation was considered successful when the grafted rootstock in vitro still green, started sprouting and continued growth), survival \% at 2- month-old grafts in greenhouse, and the whole growth vigor of the grafted plantlets at one-, 2-, 4and 6 - month- old in both seasons of study. The later parameter was presented through the measurement of three physical characteristics on the grafted seedlings, average leaves number, plantlets length and shoot length per graft per graft partners under study at the four successive ages

Statistical analysis. Micro-grafting experiment were designed as two treatment, 10 replicates each. The obtained data were subjected to analysis of variance (ANOVA) by the general linear models (GLMs) procedure using statistical analysis system (2005) (SAS). Mean comparison was performed using the least significant difference (LSD) method at $5 \%$ level according to Gomez and Gomez (1984).

\section{RESULTS AND DISCUSSION}

The obtained results in the present investigation indicated that the type of explants, growth regulators used either the concentration or the applied procedure (solely or in combinations) are necessary factors for in vitro growth and development of the cultured explants. Therefore, this study compared the effect of these factors on in vitro shoot and root proliferation on two explants type (shoot tips and epicotyls) and showed the range of responses to micro-propagation of Volkamer lemon rootstock, not previously studied so far according to our information. Before going further, it might be interesting to darity the goal of our use the reason to use the MS (1962) as the basal medium. The importance of such medium was resulted from the suggestion that the development of a truly optimal mineral formulation may be practically impossible. Nevertheless, the MS (1962) formula represents an approximation to this and has proved superior to all other mineral formulations for tissue culturing of several plant species and cultivars (Wordle, et al., 1983; Ochatt and De-Azkue, 1986). In the same line, Barless and Skene, (1982) reported that the media used for micro-propagation of Citrus tissue have largely involved the basal salts of Murashigo and Skooge (1962) for shoot regeneration. Parthasarathy and Nagaraju, (1995) came to a similar result with in vitro culture of 7 Citrus species. Pure Difco Bacto-agar added to the basal medium based on, agar has been the most commonly used gelling agent in tissue culture. However, the gel purity has affected the 
gel solidity (Debergh, 1983), the nutrient status of the medium (Singha, et al., 1985) and culture success in vitro.

The results concerned explants type pointed to epicotyls as the preferred explants to in vitro propagation of rootstock under study. They indicated an increasing effect on shoot multiplication percentage higher than shoot tip ones on basal medium containing the combined two growth regulators at all tested concentrations (Table 1 and Figure1). In the same line, the results in Tables (2, 3 and 4) and illustrated in Figure (2) concerned the effect of explants type on average leaves and shoots number confirmed the superiority of epicotyls to the shoot tip ones on these characteristics. It was also observed from Table (1) that the applied BAP at the higher concentrations (1.25 and $1.50 \mathrm{mg} / \mathrm{L})$ increased shoot multiplication\% at any concentration of Kin used and the minimum values were resulted on explants cultured on MS basal medium BAP-free. The constant and lower effect on both explants type on medium BAP-free or combined with Kin at any concentration proved the superiority of BAP to Kin. The statistical analysis technique used to indicate the effect of each growth regulator applied either solely or in different combinations (interactions) also reaffirmed the importance of BAP during proliferation stage as it is considered the limited factor affecting characteristics of proliferated shoots on both explants type.

Table (1): Effect of the interactions between explant type and certain concentrations of BAP and Kin on shoot multiplication \% during proliferation stage of Volkamer lemon explants cultured for 4 weeks on MS solid media.

\begin{tabular}{|c|c|c|c|c|}
\hline \multirow{2}{*}{ Explant type (A) } & \multirow{2}{*}{$\begin{array}{c}\text { BAP } \\
(\mathrm{mg} / \mathrm{L})(\mathrm{B})\end{array}$} & \multicolumn{3}{|c|}{ Kin (mg/L) (C) } \\
\hline & & 0.25 & 0.50 & 1.0 \\
\hline \multirow{7}{*}{ Shoot tip } & 0.0 & 10 & 0 & 20 \\
\hline & 0.25 & 40 & 20 & 20 \\
\hline & 0.50 & 50 & 30 & 40 \\
\hline & 0.75 & 50 & 60 & 40 \\
\hline & 1.0 & 60 & 60 & 70 \\
\hline & 1.25 & 70 & 70 & 80 \\
\hline & 1.50 & 80 & 100 & 100 \\
\hline \multirow{7}{*}{ Epicotyl } & 0.0 & 40 & 20 & 40 \\
\hline & 0.25 & 70 & 40 & 80 \\
\hline & 0.50 & 80 & 70 & 80 \\
\hline & 0.75 & 80 & 70 & 100 \\
\hline & 1.0 & 90 & 80 & 100 \\
\hline & 1.25 & 90 & 90 & 100 \\
\hline & 1.50 & 90 & 100 & 100 \\
\hline L.S.D 5\% & \multicolumn{4}{|c|}{5.68} \\
\hline
\end{tabular}

The superiority was to BAP concentration at $1.50 \mathrm{mg} / \mathrm{L}$. It was the best to produce significantly the highest leaves and shoots number on Volkamer lemon explants (Tables 2 to 4 and Figures 1\&2) if compared with the same explants on medium BAP-free or at the lowest concentration $(0.25$ $\mathrm{mg} / \mathrm{L})$. 
Table (2): Effect of explant type and MS medium at full strength supplemented with BAP and Kin at different concentrations on average leaves number, shoots length and shoots number per explant during proliferation stage of Volkamer lemon explants cultured for 4 weeks on MS solid media.

\begin{tabular}{|c|c|c|c|c|}
\hline \multirow{3}{*}{$\begin{array}{c}\text { Explant type } \\
\text { (A) }\end{array}$} & Treatments & number of leaves & length of shoots(cm) & number of shoots \\
\cline { 2 - 5 } & Shoot tip & 5.39 & 1.02 & 1.94 \\
\cline { 2 - 5 } & Epicotyl & 8.72 & 0.84 & 3.07 \\
\cline { 2 - 5 } & L.S.D 5\% & 0.75 & NS & 0.76 \\
\hline \multirow{4}{*}{$\begin{array}{c}\text { concentrations } \\
\text { ( mg/L) (B) }\end{array}$} & 0.0 & 4.02 & 1.48 & 1.08 \\
\cline { 2 - 5 } & 0.25 & 6.45 & 1.09 & 1.48 \\
\cline { 2 - 5 } & 0.50 & 6.67 & 0.99 & 2.00 \\
\cline { 2 - 5 } & 0.75 & 6.38 & 0.94 & 2.18 \\
\cline { 2 - 5 } & 1.0 & 6.53 & 0.84 & 2.23 \\
\cline { 2 - 5 } & 1.25 & 8.91 & 0.60 & 2.60 \\
\hline \multirow{3}{*}{ Kin conc. (mg/L) } & 1.50 & 10.45 & 0.54 & 5.97 \\
\cline { 2 - 5 }$(\mathbf{C})$ & $0.5 . D 5 \%$ & 0.19 & 0.09 & 0.20 \\
\cline { 2 - 5 } & 1.0 & 6.51 & 1.03 & 2.04 \\
\cline { 2 - 5 } & L.S.D 5\% & 6.96 & 0.93 & 3.39 \\
\hline
\end{tabular}

An additional support to the superiority of BAP, could be observed from a comparison between BAP and Kin results in the same tables. Since it was cleared that the response of both explants to BAP especially at the highest concentration $(1.50 \mathrm{mg} / \mathrm{L})$ was greater than to Kin concentrations used. The Kin results in the same tables indicated that its application at 1.00 $\mathrm{mg} / \mathrm{L}$ counted averages for leaves and shoots number per explant higher than the lower concentrations.

As for average shoot length, a negative association was observed between BAP and Kin concentration and average shoot length. The highest value was resulted on Control medium (Table 5 and Figure 3). One possibility for this reduction in shoot length is in one side the higher number of proliferated shoots which are generated on the cultured explants. On the other side, to the present inverse relationship between gelling agent concentration and shoot length produced. This relationship was previously reported by Sengha, (1982) with Almay crabapple and Seckel pear cultures as agar's inhibitory action that has been related to decreased uptake of medium constituents (Debergh, 1983; Singha, et al., 1985) and decreased availability of water (Stoltz, 1971).

The effective role of BAP on shoot proliferation was previously confirmed on several studies. It has been used for in vitro axillary shoot proliferation on explants of Citrus species and varieties or others (Baruah et al., 1996; Ramsunder et al., 1998; \& EL-KHawari \& El-Bahrany, 2001) In the same line, Krishan Kumar, et al., (2001) worked with sweet orange and proved that BAP is suitable for best shoot proliferation on in vitro epicotyls segment. More recent, Almeida et al., (2002) came to a similar results with Citrus sinensis and C. limonia. Similar observation on apples was detected by Sadlak et al. (2006) who reported that the highest shoot proliferation rate was obtained on MS medium with $1.00 \mathrm{mg} / \mathrm{L} \mathrm{BAP}$. 
Samaan, L. G. et al.

Table (3): Effect of the interactions among explant type and certain concentrations of BAP and Kin on average leaves number per explant during proliferation stage of Volkamer lemon explants cultured for 4 weeks on MS solid media.

\begin{tabular}{|c|c|c|c|c|c|}
\hline \multirow{2}{*}{ Explant type (A) } & \multirow{2}{*}{$\begin{array}{c}\text { BAP ( } \mathrm{mg} / \mathrm{L}) \\
\text { (B) }\end{array}$} & \multicolumn{3}{|c|}{$\operatorname{Kin}(\mathrm{mg} / \mathrm{L})(\mathrm{C})$} & \multirow{2}{*}{$\begin{array}{c}\text { Mean of } \\
(A \times B)\end{array}$} \\
\hline & & 0.25 & 0.50 & 1.0 & \\
\hline \multirow{7}{*}{ Shoot tip } & 0.0 & 4.10 & 4.40 & 4.60 & 4.37 \\
\hline & 0.25 & 2.90 & 3.40 & 2.70 & 3.00 \\
\hline & 0.50 & 4.00 & 4.80 & 3.80 & 4.20 \\
\hline & 0.75 & 4.60 & 5.20 & 4.90 & 4.90 \\
\hline & 1.0 & 5.10 & 5.50 & 5.00 & 5.20 \\
\hline & 1.25 & 7.30 & 7.20 & 5.30 & 6.60 \\
\hline & 1.50 & 9.90 & 9.40 & 9.20 & 9.50 \\
\hline \multicolumn{2}{|c|}{ Mean of $(A \times C)$} & 5.41 & 5.70 & 5.07 & \multirow[b]{2}{*}{3,57} \\
\hline \multirow{7}{*}{ Epicotyl } & 0.0 & 3.40 & 2.80 & 4.50 & \\
\hline & 0.25 & 5.20 & 5.60 & 4.80 & 5.20 \\
\hline & 0.50 & 7.90 & 7.40 & 9.00 & 8.10 \\
\hline & 0.75 & 8.40 & 8.20 & 10.00 & 8.87 \\
\hline & 1.0 & 9.00 & 9.10 & 12.30 & 10.13 \\
\hline & 1.25 & 9.10 & 12.10 & 12.30 & 11.17 \\
\hline & 1.50 & 10.20 & 12.40 & 19.50 & 14.03 \\
\hline \multicolumn{2}{|c|}{ Mean of $(A \times C)$} & 7.60 & 8.23 & 10.34 & \multirow{8}{*}{$\begin{array}{ll}\text { L.S.D } & 5 \% \\
\text { AB } & 0.24 \\
\text { AC } & 0.33 \\
\text { BC } & 0.23 \\
\text { ABC } & 0.28\end{array}$} \\
\hline \multirow{7}{*}{$\begin{array}{l}\text { Mean of } \\
(B \times C)\end{array}$} & 0.0 & 3.75 & 3.60 & 4.55 & \\
\hline & 0.25 & 4.05 & 4.50 & 3.75 & \\
\hline & 0.50 & 5.95 & 6.10 & 6.40 & \\
\hline & 0.75 & 6.50 & 6.70 & 7.45 & \\
\hline & 1.0 & 7.05 & 7.30 & 8.65 & \\
\hline & 1.25 & 8.20 & 9.65 & 8.80 & \\
\hline & 1.50 & 10.05 & 10.90 & 14.35 & \\
\hline
\end{tabular}
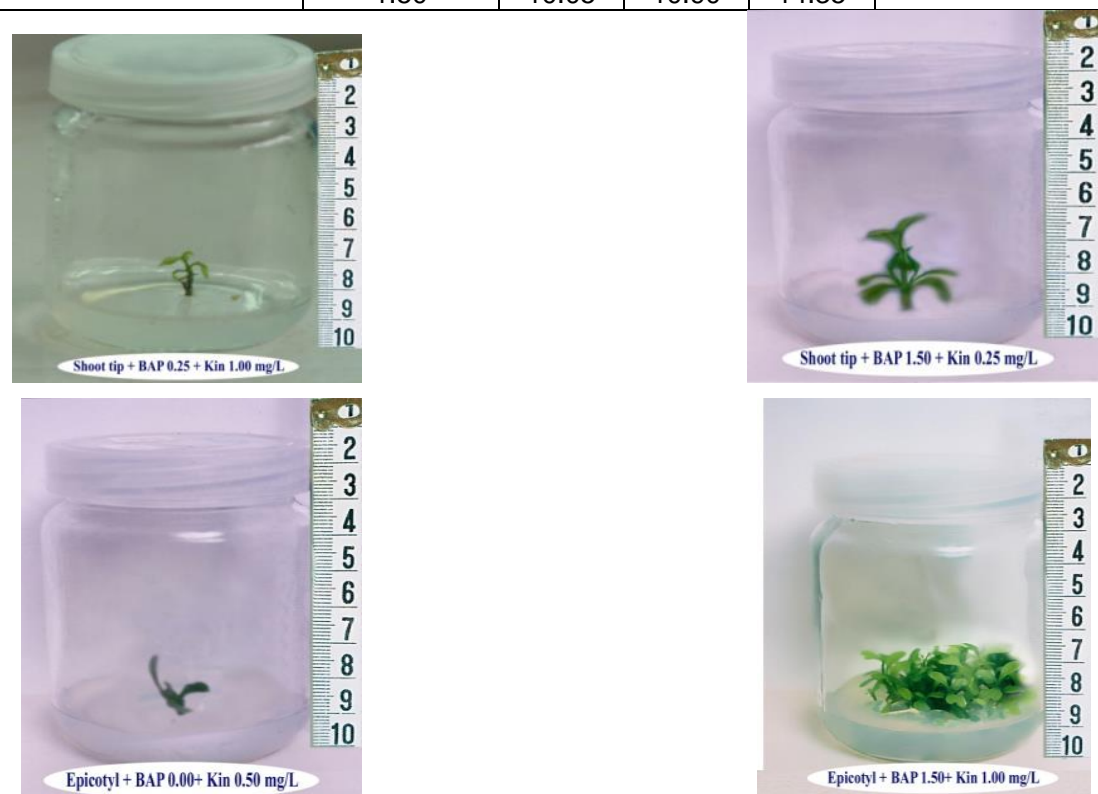

Epicotyl + BAP 0.00+ Kin 0.50 mg/L

Epicotyl + BAP 1.50+ Kin $1.00 \mathrm{mg} / \mathrm{L}$

Figure (1): Photo showing the effect of MS (1962) basal medium supplemented with different BAP and Kin concentrations $(\mathrm{mg} / \mathrm{L})$ on average number of leaves during proliferation stage of the cultured explants of Volkamer lemon rootstock for 4 weeks on MS solid media . 
Table (4): Effect of the interactions among explant type and certain concentrations of BAP and Kin on average shoot length per explant $(\mathrm{cm})$ during proliferation stage of Volkamer lemon explants cultured for 4 weeks on MS solid media.

\begin{tabular}{|c|c|c|c|c|c|}
\hline \multirow{2}{*}{ Explant type (A) } & BAP ( $\mathrm{mg} / \mathrm{L})$ & \multicolumn{3}{|c|}{ Kin $(\mathrm{mg} / \mathrm{L})(\mathrm{C})$} & \multirow{2}{*}{$\begin{array}{l}\text { Mean of } \\
(A \times B)\end{array}$} \\
\hline & (B) & 0.25 & 0.50 & 1.0 & \\
\hline \multirow{7}{*}{ Shoot tip } & 0.0 & 1.60 & 1.38 & 1.23 & 1.40 \\
\hline & 0.25 & 1.49 & 1.38 & 0.92 & 1.26 \\
\hline & 0.50 & 1.32 & 1.20 & 0.59 & 1.04 \\
\hline & 0.75 & 1.16 & 0.69 & 0.54 & 0.80 \\
\hline & 1.0 & 0.88 & 0.52 & 0.54 & 0.65 \\
\hline & 1.25 & 0.52 & 0.40 & 0.42 & 0.47 \\
\hline & 1.50 & 0.27 & 0.31 & 0.24 & 0.27 \\
\hline \multicolumn{2}{|c|}{ Mean of $(A \times C)$} & 1.03 & 0.84 & 0.64 & \\
\hline \multirow{7}{*}{ Epicotyl } & 0.0 & 2.39 & 1.71 & 1.59 & 1.90 \\
\hline & 0.25 & 1.43 & 1.56 & 1.49 & 1.50 \\
\hline & 0.50 & 0.88 & 1.11 & 1.12 & 1.04 \\
\hline & 0.75 & 0.71 & 0.84 & 0.86 & 0.80 \\
\hline & 1.0 & 0.70 & 0.62 & 0.85 & 0.72 \\
\hline & 1.25 & 0.69 & 0.60 & 0.65 & 0.65 \\
\hline & 1.50 & 0.47 & 0.59 & 0.46 & 0.51 \\
\hline \multicolumn{2}{|c|}{ Mean of $(A \times C)$} & 1.04 & 1.00 & 1.00 & \multirow{8}{*}{ 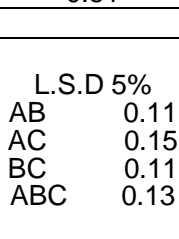 } \\
\hline \multirow{7}{*}{$\begin{array}{l}\text { Mean of } \\
(B \times C)\end{array}$} & 0.0 & 1.89 & 1.60 & 1.18 & \\
\hline & 0.25 & 1.30 & 1.47 & 1.09 & \\
\hline & 0.50 & 1.24 & 0.90 & 1.02 & \\
\hline & 0.75 & 1.01 & 1.82 & 0.70 & \\
\hline & 1.0 & 0.79 & 0.66 & 0.69 & \\
\hline & 1.25 & 0.50 & 0.58 & 0.55 & \\
\hline & 1.50 & 0.49 & 0.50 & 0.54 & \\
\hline
\end{tabular}

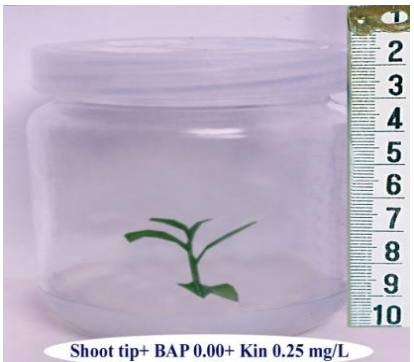

Shoot tip+ BAP $0.00+$ Kin $0.25 \mathrm{mg} / \mathrm{L}$

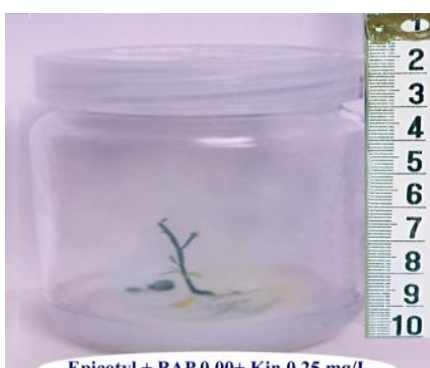

Epicotyl + BAP 0.00+ Kin $0.25 \mathrm{mg} / \mathrm{L}$

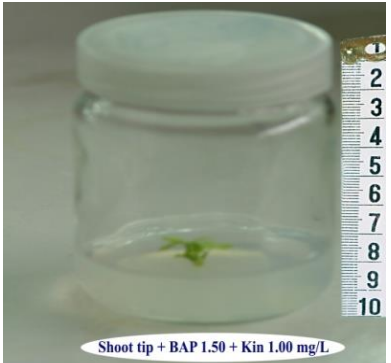

Shoot tip + BAP $1.50+$ Kin $1.00 \mathrm{mgL}$

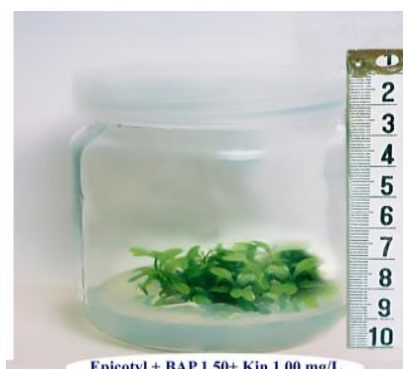

Epicoty + BAP 1.50+ Kin $1.00 \mathrm{mg} / \mathrm{L}$

Figure (2): Photo showing the effect of MS (1962) basal medium supplemented with BAP at $0.00 \& 1.50 \mathrm{mg} / \mathrm{L}$ and $\mathrm{Kin} 0.25 \& 1.00 \mathrm{mg} / \mathrm{L}$ on average shoot length during proliferation stage of the cultured explants of Volkamer lemon rootstock for 4 weeks on MS solid media. 
Samaan, L. G. et al.

During proliferation stage the different concentrations of BAP and Kin were applied to basal medium to encourage growth of axillary buds on the cultured explants. The obtained results cleared that the addition of BAP and Kin solely had an weaker effect than in combination. This finding was conducted from the tabulated data of leaves number (Table 3 and Figure 1) and shoots number (Table 4 and Figure 2) for the interactions between explants type and either BAP or Kin at the most effective concentration.

These results provide a recommendation to the use of both growth regulators at the highest concentration as a selection shoot proliferating medium. The used BAP and Kin at this concentration had a higher increasing effect on these characteristics. Therefore, medium consisted of solid MS (1962) basal medium at full strength supplemented with BAP at $1.50 \mathrm{mg} / \mathrm{L}$ and $\mathrm{Kin}$ at $1.00 \mathrm{mg} / \mathrm{L}$ plus a fixed $0.50 \mathrm{mg} \mathrm{NAA} / \mathrm{L}$ is uniquely suited to obtain the best shoot proliferation characteristics on both explants type used. Otherwise, it is important to state herein that this medium, relatively, caused a decreasing effect on average shoot length in both explants type. This means that the cultured explants on medium containing the combination of these two growth regulators at lower concentrations $(0.25$ or $0.50 \mathrm{mg} / \mathrm{L})$ were more effective to proliferate longer shoots (Table 5 and Figure3).

Table (5): Effect of the interactions among explant type and certain concentrations of BAP and Kin on average shoot number per explant during proliferation stage of Volkamer lemon explants cultured for 4 weeks on MS (1962) solid media.

\begin{tabular}{|c|c|c|c|c|c|c|}
\hline \multirow{2}{*}{ Explant type (A) } & \multirow{2}{*}{$\begin{array}{c}\text { BAP ( } \mathrm{mg} / \mathrm{L}) \\
\text { (B) }\end{array}$} & \multicolumn{3}{|c|}{ Kin $(m g / L)(C)$} & \multirow{2}{*}{\multicolumn{2}{|c|}{$\begin{array}{l}\text { Mean of } \\
(\mathrm{A} \times \mathrm{B})\end{array}$}} \\
\hline & & 0.25 & 0.50 & 1.0 & & \\
\hline \multirow{7}{*}{ Shoot tip } & 0.0 & 1.10 & 0.60 & 1.00 & \multicolumn{2}{|c|}{1.03} \\
\hline & 0.25 & 1.40 & 1.00 & 1.20 & \multicolumn{2}{|c|}{1.20} \\
\hline & 0.50 & 1.50 & 1.20 & 1.40 & \multicolumn{2}{|c|}{1.36} \\
\hline & 0.75 & 1.50 & 2.00 & 1.80 & \multicolumn{2}{|c|}{1.77} \\
\hline & 1.0 & 2.20 & 2.10 & 2.30 & \multicolumn{2}{|c|}{2.20} \\
\hline & 1.25 & 2.40 & 2.20 & 2.50 & \multicolumn{2}{|c|}{2.37} \\
\hline & 1.50 & 2.70 & 3.10 & 5.60 & \multicolumn{2}{|c|}{3.80} \\
\hline \multicolumn{2}{|c|}{ Mean of $(A \times C)$} & 1.83 & 1.74 & 2.25 & \\
\hline \multirow{7}{*}{ Epicotyl } & 0.0 & 1.10 & 0.90 & 1.20 & \multicolumn{2}{|c|}{1.07} \\
\hline & 0.25 & 1.90 & 1.10 & 2.10 & \multicolumn{2}{|c|}{1.70} \\
\hline & 0.50 & 2.00 & 2.00 & 2.10 & \multicolumn{2}{|c|}{2.03} \\
\hline & 0.75 & 2.30 & 2.60 & 2.90 & \multicolumn{2}{|c|}{2.60} \\
\hline & 1.0 & 2.70 & 2.70 & 3.30 & \multicolumn{2}{|c|}{2.90} \\
\hline & 1.25 & 3.10 & 2.70 & 3.40 & \multicolumn{2}{|c|}{3.07} \\
\hline & 1.50 & 3.40 & 4.40 & 16.60 & \multicolumn{2}{|c|}{8.13} \\
\hline \multicolumn{2}{|c|}{ Mean of $(A \times C)$} & 2.36 & 2.34 & 4.51 & \multirow{3}{*}{\multicolumn{2}{|c|}{ L.S.D 5\% }} \\
\hline \multirow{7}{*}{$\begin{array}{l}\text { Mean of } \\
(B \times C)\end{array}$} & 0.0 & 1.10 & 0.85 & 1.20 & & \\
\hline & 0.25 & 1.65 & 0.95 & 1.95 & & \\
\hline & 0.50 & 1.75 & 1.90 & 1.95 & \multirow{5}{*}{$\begin{array}{l}A B \\
A C \\
B C \\
A B C\end{array}$} & 0.24 \\
\hline & 0.75 & 1.90 & 2.00 & 2.20 & & 0.34 \\
\hline & 1.0 & 2.45 & 2.40 & 2.35 & & 0.24 \\
\hline & 1.25 & 2.75 & 2.45 & 2.95 & & 0.28 \\
\hline & 1.50 & 3.05 & 3.75 & 11.10 & & \\
\hline
\end{tabular}



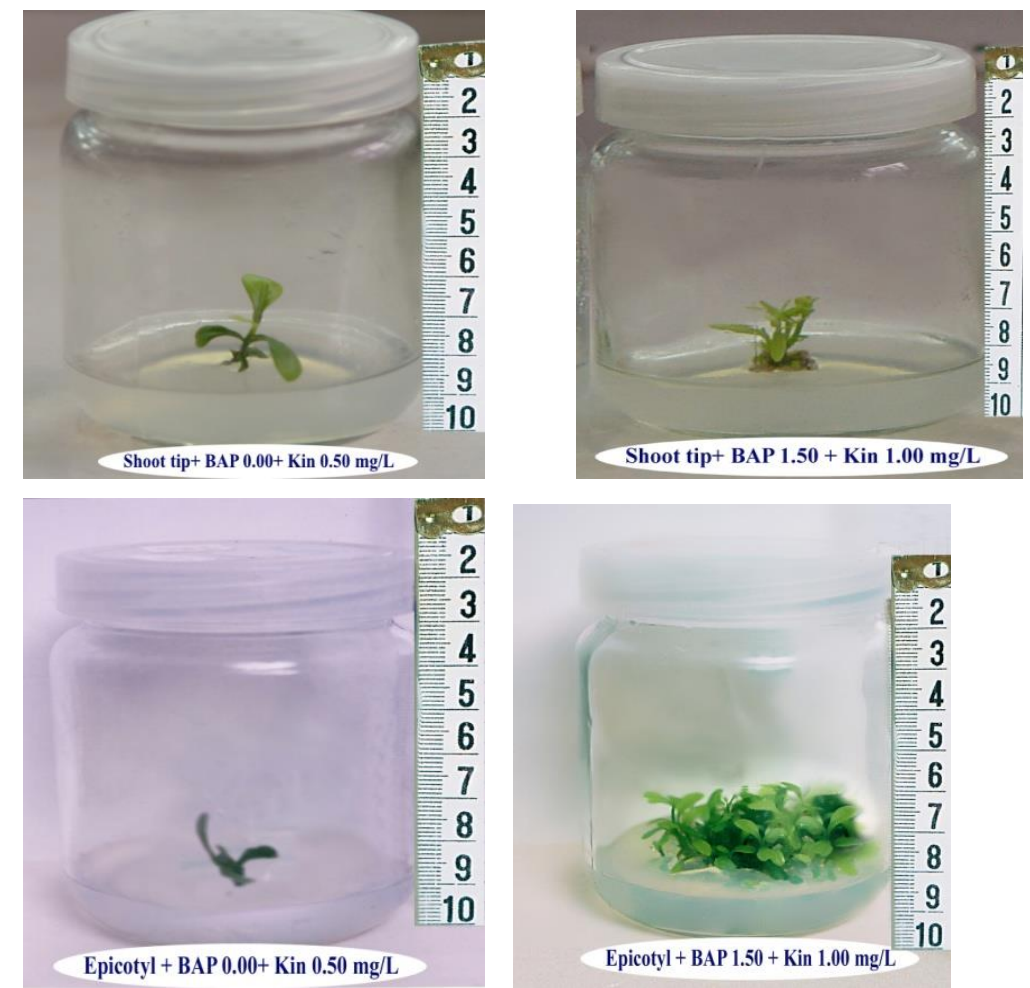

Figure (3): Photo showing the effect of MS (1962) basal medium supplemented with different BAP and Kin concentrations(mg/L) on average shoot number during proliferation stage of the cultured explants of Volkamer lemon rootstock for 4 weeks on MS solid media.

Cytokinins often employed are BAP, BA and Kinetin for in vitro shoot proliferation. The results of Singh, et al. (1995); Baruah, et al. (1996) and Krishan-Kumar, et al. (2001) who worked on micro-propagation of certain Citrus species using Cytokinins (BAP and Kin) either alone or combined with NAA and proved them to be suitable for shoot proliferation of best characteristics. In the same line, EL-Bahrany, (2001) working on lime node explants found that in vitro proliferated shoots number per node was the greatest on MS medium containing BAP at $0.50 \mathrm{mg} / \mathrm{L}$ and $\mathrm{Kin}$ at $1.00 \mathrm{mg} / \mathrm{L}$ plus $0.50 \mathrm{mg} \mathrm{NAA} / \mathrm{L}$. These results are in complete agreement with our results obtained.

As for rooting experiments, result of preliminary experiments indicated that in vitro culturing cuttings of regenerated shoots could be rooted. We investigated $A$ number of factors that have been shown affect rooting in vitro were investigative. These factors included explants Type, auxin kind and concentration. Quantity and quality of such effect were represented by the measurement of three characteristics on the proliferated 
roots. Cuttings were cultured on MA (1962) solid basal medium at full strength in complete formation for 6 weeks. The obtained results of the former factor indicated that rooting cuttings of epicotyls was accomplished more successfully in vitro.

These in the laboratory had significantly greater average roots number, longer main roots and average root diameter per cutting (Table 6). Accordingly, epicotyls would be the desirable source for Volkamer lemon cuttings for rooting.

Considering results related to the other factor (Auxin type and concentration), It was found a linear association between the concentration of combined NAA+IBA and the value of measured root characteristics. This association nearly was observed with all characteristics measured. Therefore, it could be stated that among the used rooting media the MS (1962) basal medium at full strength supplemented with NAA and IBA in combination at $2.00 \mathrm{mg} / \mathrm{L}$ each plus a fixed $0.50 \mathrm{mgKin} / \mathrm{L}$ is the promising rooting medium for in vitro culturing cuttings of Volkamer lemon explants. The cultured cuttings on this super medium produced significantly the greatest average roots number, the longest proliferated roots and almost the biggest average root diameter per cutting (Table 6).

Table (6): Effect of explant type, IBA + NAA concentrations and their interactions on average roots number, roots length $(\mathrm{cm})$ and roots diameter $(\mathrm{mm})$ per cutting during rooting stage of Volkamer lemon explants cultured for six weeks on MS solid media.

Average roots number

\begin{tabular}{|c|c|c|c|c|c|}
\hline \multirow{2}{*}{$\begin{array}{c}\text { Explant type } \\
\text { (A) }\end{array}$} & \multicolumn{4}{|c|}{ NAA + IBA(mg/L) (B) } & \multirow{2}{*}{ Mean of (A) } \\
\cline { 2 - 5 } & $\mathbf{0 . 5 0}$ & $\mathbf{1 . 0 0}$ & $\mathbf{1 . 5 0}$ & $\mathbf{2 . 0 0}$ & 3.08 \\
\hline Shoot tip & 1.50 & 2.70 & 3.60 & 4.50 & 3.58 \\
\hline Epicotyl & 1.70 & 3.40 & 4.00 & 5.20 & \\
\hline Mean of (B) & 1.60 & 3.05 & 3.80 & 4.85 & $(\mathrm{AB})$ \\
\hline L.S.D 5\% & \multicolumn{5}{|c|}{ (B) } \\
& (A) NS & \multicolumn{3}{c|}{0.24} \\
\hline
\end{tabular}

\begin{tabular}{|c|c|c|c|c|c|}
\hline \multicolumn{7}{|c|}{ Average root length } & \multirow{2}{*}{ Mean of (A) } \\
\cline { 2 - 5 } $\begin{array}{c}\text { Explant type } \\
\text { (A) }\end{array}$ & $\mathbf{0 . 5 0}$ & $\mathbf{1 . 0 0}$ & $\mathbf{1 . 5 0}$ & $\mathbf{2 . 0 0}$ & \\
\hline Shoot tip & 1.25 & 2.77 & 4.28 & 5.50 & 3.45 \\
\hline Epicotyl & 1.38 & 3.10 & 3.78 & 5.78 & 3.51 \\
\hline Mean of (B) & 1.32 & 2.94 & 4.03 & 5.64 & \\
\hline L.S.D 5\% & \multicolumn{5}{c|}{ (B) } \\
\end{tabular}

\begin{tabular}{|c|c|c|c|c|c|}
\hline \multicolumn{7}{|c|}{ Average root diameter } \\
\hline \multirow{2}{*}{$\begin{array}{c}\text { Explant type } \\
\text { (A) }\end{array}$} & $\mathbf{0 . 5 0}$ & $\mathbf{1 . 0 0}$ & $\mathbf{1 . 5 0}$ & $\mathbf{2 . 0 0}$ & \multirow{2}{*}{ Mean of (A) } \\
\cline { 2 - 5 } & 0.28 & 0.29 & 0.39 & 0.43 & 0.35 \\
\hline Shoot tip & 0.30 & 0.35 & 0.42 & 0.43 & 0.38 \\
\hline Epicotyl & 0.32 & 0.41 & 0.43 & \\
\hline Mean of (B) & 0.29 & 0.32 & (AB) \\
\hline \multirow{2}{*}{ L.S.D 5\% } & \multicolumn{7}{|c|}{ (A) NS } & (B) & 0.09 \\
\hline
\end{tabular}


On the other hand, the same MS medium containing the least concentration of such combined auxins $(0.50 \mathrm{mg} / \mathrm{L}$ each $)$ is not recommended, since culturing both types of cutting on it recorded the lowest value of root characteristics (Table 6). These results are strongly confirmed by a number of reports in the field of in vitro root proliferation on Citrus explants (Pasqual and Ando, 1990; Can, et al., 1992 and Prez, et al., 1997). They all found positive effects on root proliferation to the use of MS medium supplemented with NAA and IBA combined ether solely or in combinations at similar or close to the concentration recommended in the present research. More recent, our results are also in complete agreement with those of Albahrany, (2001) who worked with in vitro lime shoots rooting and recommended the rooting medium consisted of MS basal medium containing IBA and NAA at $2.00 \mathrm{mg} / \mathrm{L}$ each as the best rooting medium.
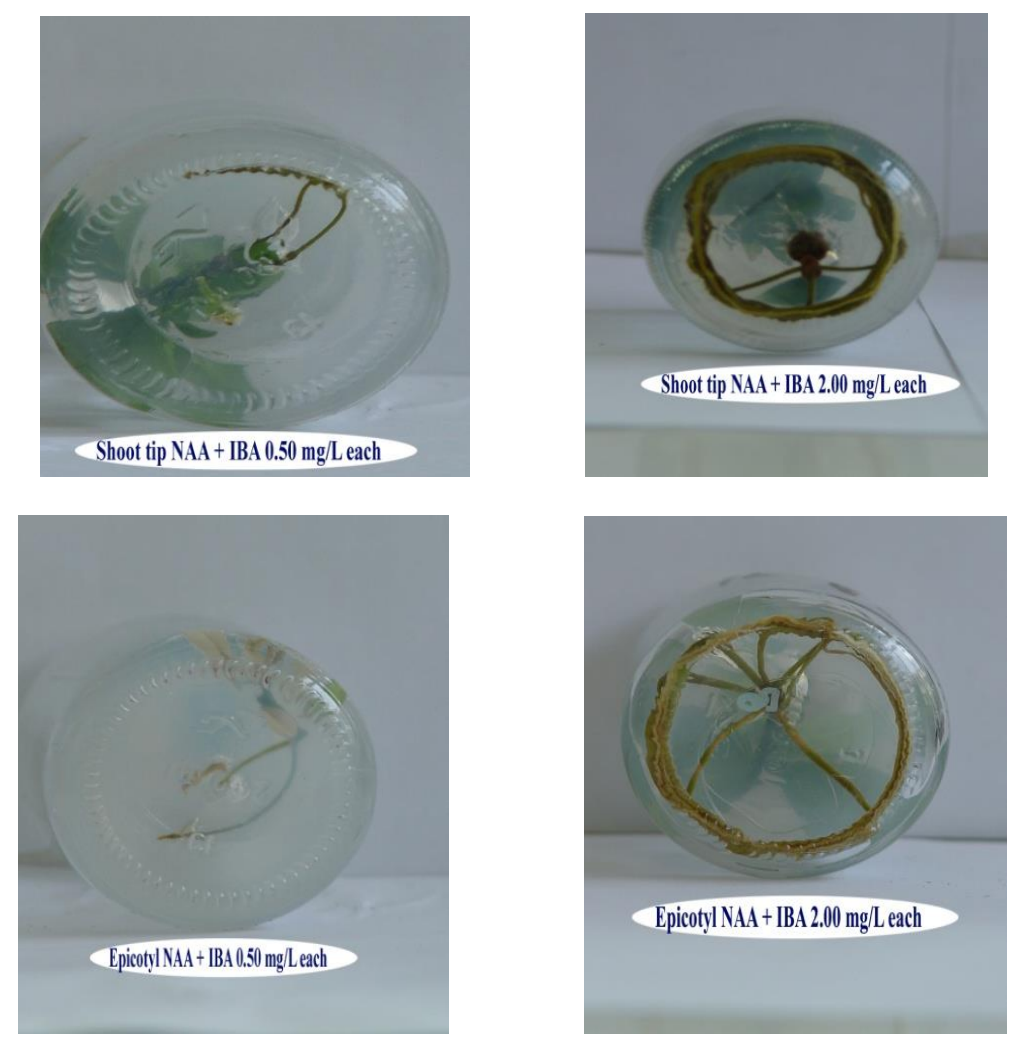

Figure (4): Photo showing the effect of explant type cultured on MS (1962) basal medium supplemented with NAA + IBA at 0.5 and $2.0 \mathrm{mg} / \mathrm{L}$ each on average roots length per cutting during rooting stage of Volkamer lemon explants cultured for 6 weeks on MS solid media. 


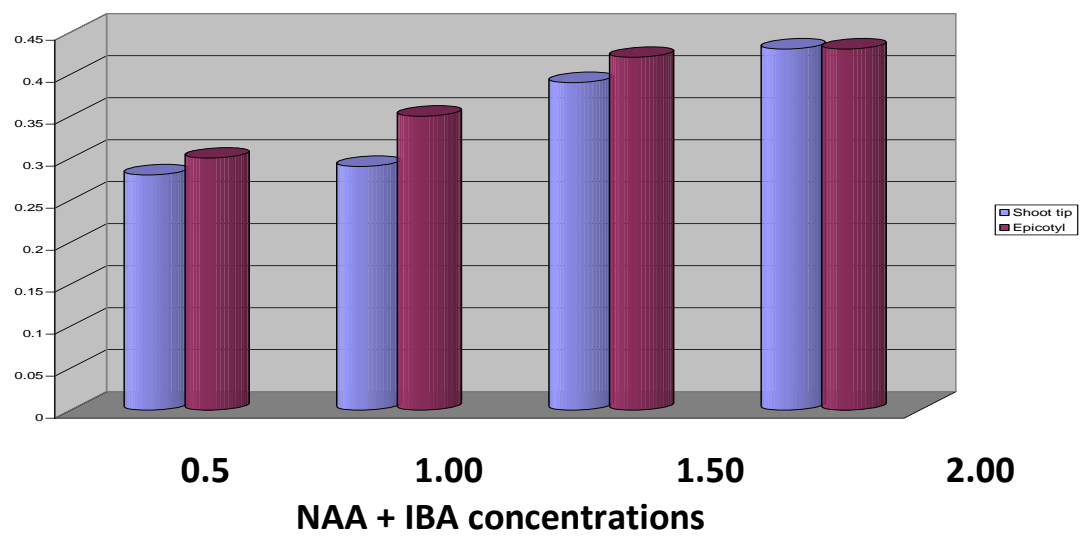

Figure (5): Diagram showing the effect of explant type cultured on MS (1962) basal medium supplemented with NAA + IBA at 0.5 and $2.0 \mathrm{mg} / \mathrm{L}$ on average roots diameter per cutting during rooting stage of Sour orange explants cultured for 6 weeks.

Likewise, the present results partially agreed with those obtained in the studies of Moreira-Das, et al., (2000); Al-Khayari \& AL-Bahrany,( 2001); and Kaya \& Gubbuc,( 2001) who tested the effect of certain auxins at various concentrations used either alone or in combinations to induce adventitious roots formation on Citrus regenerated shoots. On the other hand, our findings are contradicted with Lukman, et al. (1990) who found non apparent effect of NAA on promoting rooting on cultured shoot apices of Troyer citrange.

Regarding the results of both shoot and root proliferation on Volkamer lemon explants, it could be recommended that MS (1962) basal medium at full strength supplemented with BAP at $1.50 \mathrm{mg} / \mathrm{L}$ and $\mathrm{Kin}$ at $1.00 \mathrm{mg} / \mathrm{L}$ plus a fixed $0.50 \mathrm{mgNAA} / \mathrm{L}$ as the uniquely suited for shoots proliferation and the same basal medium combined with NAA and IBA at 2.00 $\mathrm{mg} / \mathrm{L}$ each plus a fixed $0.50 \mathrm{mg} \mathrm{Kin} / \mathrm{L}$ as the best rooting medium. Such recommended media succeeded to induce best proliferated shoots and roots for both explants type. Culturing epicotyls explants were superior to proliferate shoots and roots of a higher qualities.

Micro-propagation of Volkamer lemon Citrus rootstock in the present research and the applicability to extend to other Citrus trees and fruit crops succeeded to eliminate some difficulties of the conventional currently method of propagation.. It allows the production of a great number of genetically identical plants from small pieces of stock plants in relatively short period of time which accelerated asexual propagation (Matsumoto, et al., 2000). In addition, the original tissue explants, with most species, does not destroy the parent plant. Once it is established actively divided to be a continuous source of micro-cuttings which can result in plant production under greenhouse conditions without seasonal interruption. In the same line, Mas Camacho, et al., (1991) reported that in vitro propagation of Citrus permits the production of disease-free planting materials which allows transport and introduction of 
vegetative material without the risk of disease transmission. This is advantageous over the traditional quarantine system.

Micro-grafting experiment in this investigation was worked with plantlet shoots at 4-week-old resulted from in vitro cultures seeds of Volkamer lemon mature fruits. Seed culturing, scion and rootstock preparation, micro-grafting process, acclimatization and care of micro-grafts were explained before in Materials and Methods of this study. The obtained graft combinations were subjected to measure three main parameters well known as criteria for the degree of scion-rootstock compatibility. They are micro-grafting success and graft survival percentages and the whole growth vigor of graft seedlings at one-, 2-, 4- and 6-month-old. The obtained results showed in one side that both Washington navel and Valencia scions made successful graft unions with a degree of graft compatibility onto Volkamer lemon rootstock. On the other side, it could be stated that this rootstock is considered one of the promising stock to such scions. The values resulted in the measurements of graft compatibility criteria, if they were compared, to the results obtained:

\section{Calculation of grafting success and survival percentages:}

The obtained two micro-graft combinations were standardized. To make micro-grafting more economical, the success and growth of grafts were evaluated either in vitro as grafting success\% at one-month-old or in greenhouse as graft survival\% at 2-month-old (Table 7). The concerned results in this table revealed that Valencia scions onto Volkamer lemon significantly calculated values for these two parameters greater than Washington navel scions onto the same rootstock at the two successive ages in both seasons of study. It is important to indicate herein that the micrografts in vitro were considered successful when the bud wood was still green and starting sprouting and continued growth till 6-month-old in greenhouse (Rouse, 1988). According to the previous confirmation of these parameters as an index for scion - rootstock compatibility in different fruit trees (Williamson et al., 1992; Guindy et al., 1995 and Samaan et al., 2000), it could be stated that Valencia scions onto Volkamer lemon rootstock had a degree of graft compatibility higher than Washington navel onto the same rootstock.

Table (7): Micrografting success and grafts Survival percentages of micrograft combinations between Washington navel and Valencia scions onto Volkamer lemon Citrus rootstock at 2 successive ages.

\begin{tabular}{|c|c|c|c|c|c|c|c|}
\hline \multirow{2}{*}{\multicolumn{2}{|c|}{ Graft participations }} & \multirow{2}{*}{\multicolumn{2}{|c|}{$\begin{array}{c}\text { Grafting success \% } \\
\text { One - month - old }\end{array}$}} & \multirow{3}{*}{$\mathbf{X}$} & \multirow{2}{*}{\multicolumn{2}{|c|}{$\begin{array}{l}\text { Grafts survival \% } \\
\text { two - month - old }\end{array}$}} & \multirow{3}{*}{$\mathbf{X}$} \\
\hline & & & & & & & \\
\hline Rootstock & Scion & $1^{\text {st }}$ culture & Re - culture & & $1^{\text {st }}$ season & $\begin{array}{c}2^{\text {nd }} \\
\text { season }\end{array}$ & \\
\hline \multirow{2}{*}{$\begin{array}{l}\text { Volkamer } \\
\text { lemon }\end{array}$} & W. navel & 53.33 & 51.60 & 52.47 & 50.00 & 52.23 & 51.12 \\
\hline & Valencia & 93.33 & 94.45 & 93.89 & 92.80 & 93.90 & 93.35 \\
\hline \multicolumn{2}{|c|}{ L.S.D $5 \%$} & 6.53 & 6.50 & & 5.16 & 5.17 & \\
\hline
\end{tabular}


Standardization of grafts whole growth vigor :

Measurements of three physical characteristics on the grafted seedlings at four successive stages in both seasons were used in that respect (Table 8). Date recorded in this table and illustrated in Figures (6 and 7) greatly confirmed the results of the above two parameters. Since Valencia scions onto Volkamer lemon rootstock had a degree of compatibility higher than that of Washington navel scions onto the same rootstock. In the two tested seasons, micro-grafts of the former graft combination produced an average leaves number, seedling length and shoot length significantly higher than those of the later one. This statement was based on the acceptance of whole growth as a criterion for graft compatibility as previously confirmed in several studies (Hartmann, et al., 1990; Misra et al., 1995; and Samaan et al., 2000).

The successful application of tissue culture technique in micrografting of Volkamer lemon rootstock in this study offers certain advantages not possible with conventional grafting techniques. In the same time alleviate some of difficulties limitations.

Table (8): leaves number, seedling length and shoot length measurements representing the whole growth of Washington navel and Valencia scions onto Volkamer lemon citrus rootstock at 4 successive ages.

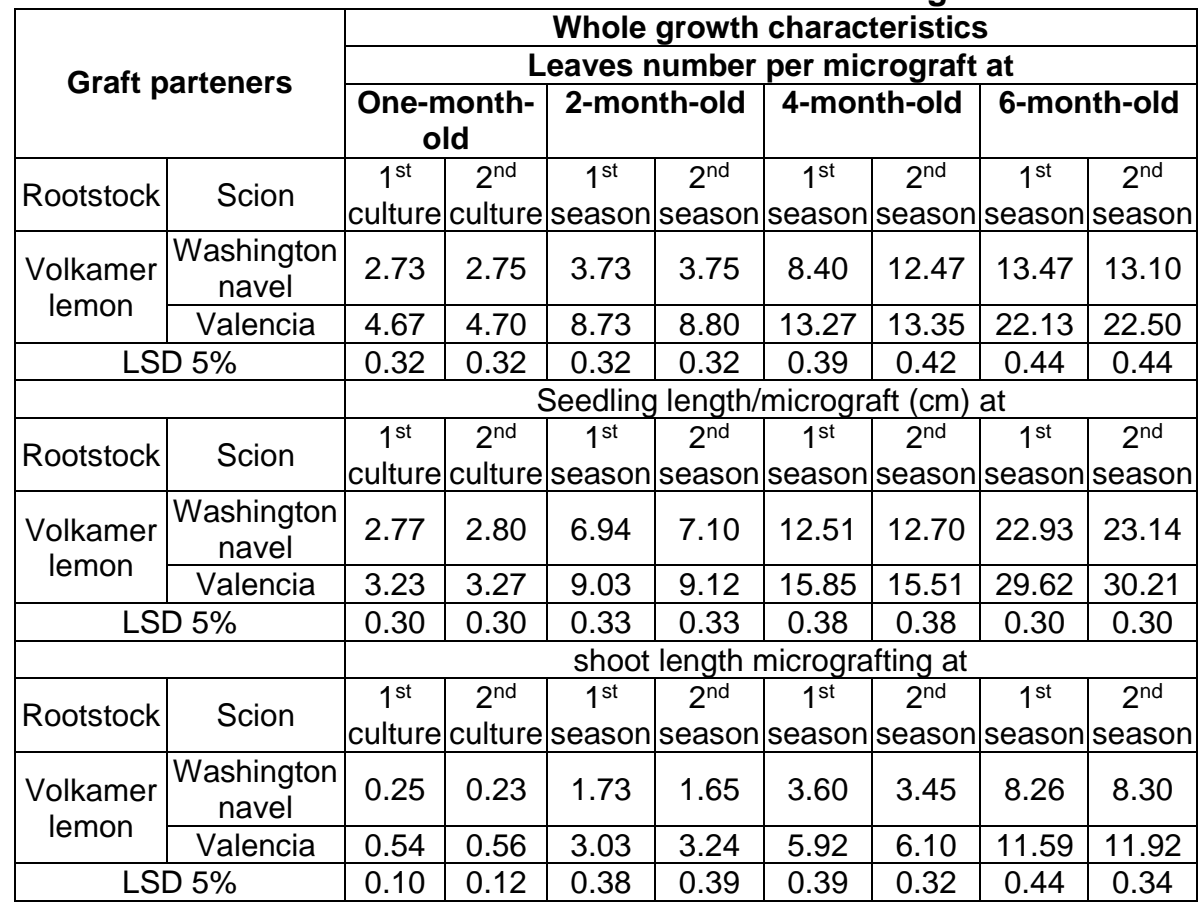




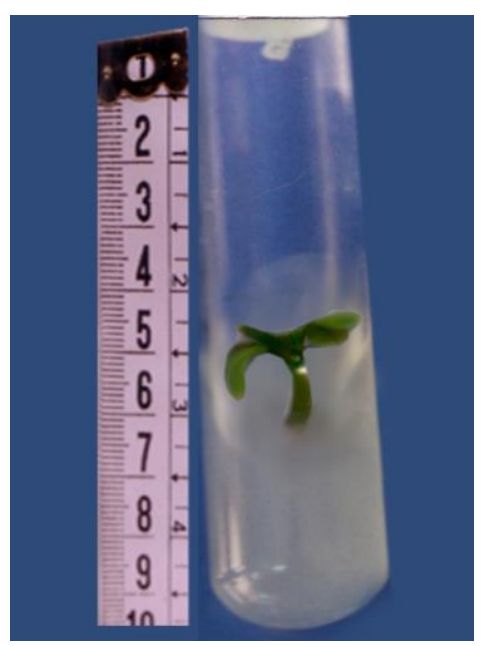

(A)

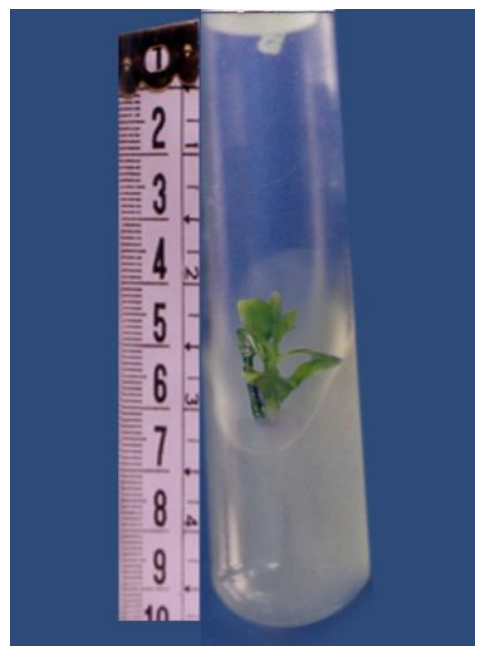

(A1)

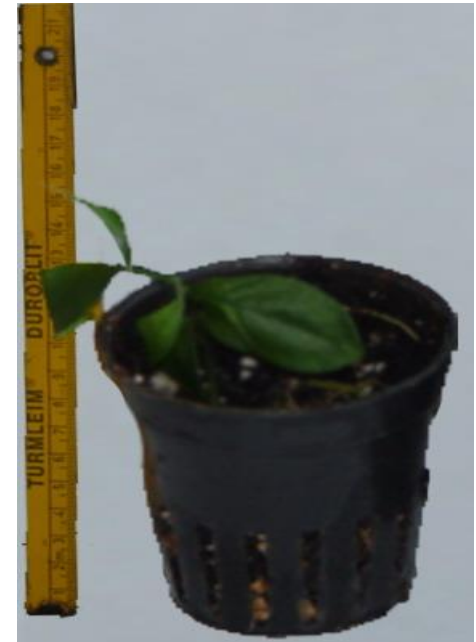

(B)

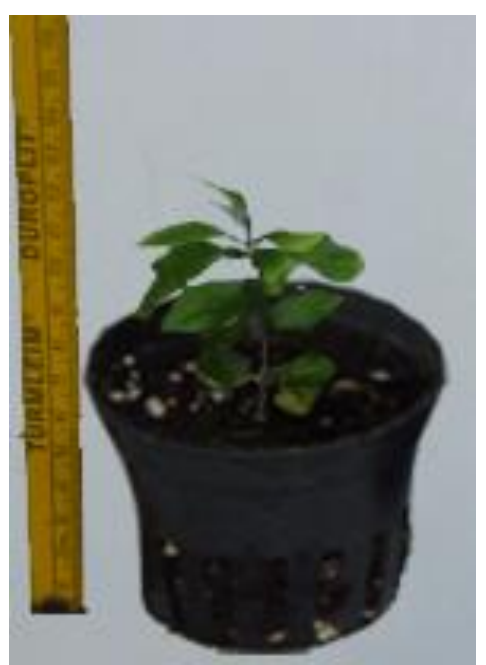

(B1)

Figure (6): Photograph showing micrograft combinations of Volkamer lemon rootstock with Washington navel and Valencia scions.

A- Washington navel onto Volkamer lemon rootstock at one-month-old. B- Washington navel onto Volkamer lemon rootstock at 2-month-old. A1- Valencia onto Volkamer lemon rootstock at one-month-old. B1- Valencia onto Volkamer lemon rootstock at 2-month-old. 
Samaan, L. G. et al.

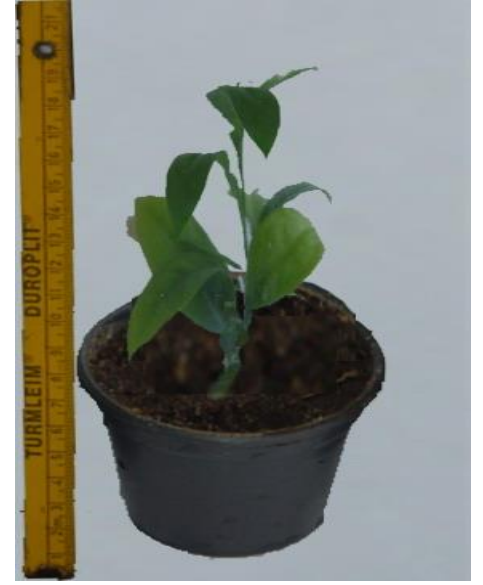

(C)

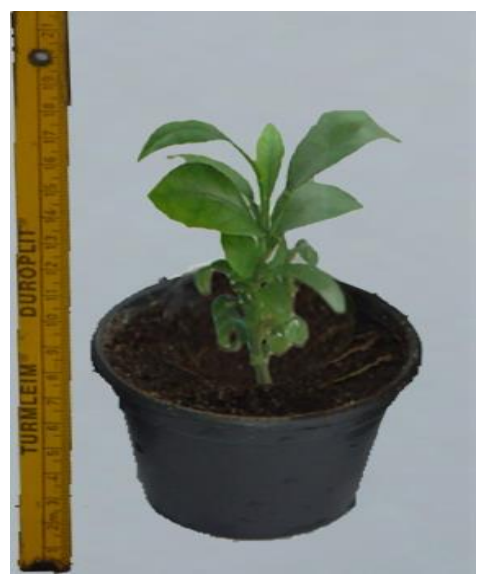

(C1)

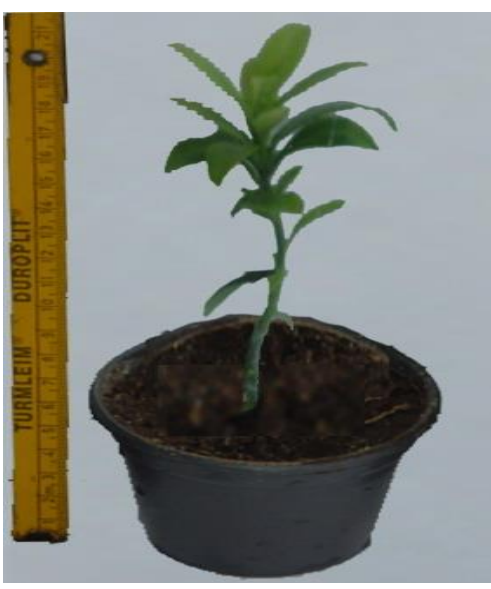

(D)

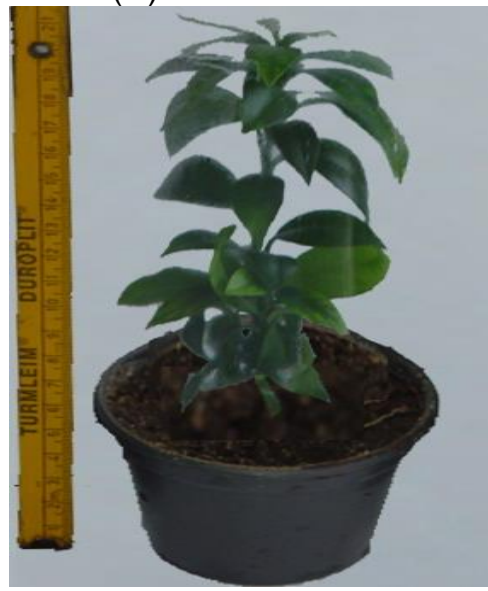

(D1)

Figure (7): Photograph showing micrograft combination of Volkamer lemon rootstock with Washington navel and Valencia scions.

C- Washington navel onto Volkamer lemon rootstock at 4-month-old.

D- Washington navel onto Volkamer lemon rootstock at 6-month-old.

C1- Valencia onto Volkamer lemon rootstock at 4-month-old.

D1- Valencia onto Volkamer lemon rootstock at 6-month-old.

These were explained in the studies of Obeidy \& Smith (1991) as elimination of viruses, the early diagnosis of grafting incompatibilities, and the rejuvenation of mature tissue and bypass the juvenile phase in fruit trees. Ke et al. (1993) added that it succeeded to shorten the time required for transfer the grafted plants to field. In the same line, Navarro et al. (1975) and Singh et al. (2008) pointed to the importance of rootstock age. The younger the rootstock seedlings (one or 2-week-old) the higher the grafting success. They attributed this higher success to their capability to cover most shoot tips grafted onto them with precocious callus formation. Otherwise, most shoot tips grafted on older rootstocks were dried, turned brown and died. 
Vijayakumari \& Singh, (2003) also reported that micro-budding propagation technique is applicable for fast getting the marketable budded seedlings earlier with reduced cost. On the other hand, the conventional budding is season dependent, limited and requires longer time for field release budgrafts. In addition to these advantages, the ability of Citrus tissue culture regenerators to grow on different rootstocks basing on the existence of in vitro micro-grafting and the success of this technique help to clear difficulties to several Citrus cultivars, which selected for fruit qualities, do not have a good root system in terms of growth rate, disease resistance, soil adaptation, etc. This is of great economic benefits in the field of Citrus trees propagation.

\section{REFERENCES}

AL-Khayri, J.M. and A.M. AL-Bahrany.(2001). In vitro micro-propagation of lime (Citrus aurantifolia L.). Current Science, 81(9):10.

Almeida, W.A.; F.A. Mourao Filho; B.M. Mendes and A.P. Rodriguez.(2002). In vitro organogenesis optimization and plantlet regeneration in Citrus sinensis and C. Limonia. Scientia Agricola, 59 (1): 35-40.

Barlass, M and KGM Sken. (1982). In vitro plantlet formation from Citrus species and hybrids. Sci. Hortic., 17: 333-341.

Baruah, A.; V. Nagaraju and V'. A. Parthasarathy.(1996).Micro-propagation of three Endangered Citrus species. 1. Shoot proliferation in vitro. Ann. Plant Phys., 10(2):124-28.

Bordon, Y., L.J.Guardiola, and A. Garcia-Luis.(2000). Genotype affects the morphogenetic response in vitro of epicotyls segments of Citrus rootstocks. Ann. Bot., 86: 159-166.

Can C.; N.K. Koc and J.D. Cinar.(1992). In vitro clonal propagation of sour orange by epicotyls Segments. Doga Turk Tarim ve Orman Vilik Dergisi, 16 (1): 132-139.

Debergh, P.C. (1983). Effect of agar brand and concentration on tissue culture medium. Physiol. Plant., 51: 270-276.

DeCleene, M. and D.J. Ley.(1976). The host range of crown gell. Bot. Rev., $42: 389-466$.

Edriss, M.H. and D.W. Burger(1984). Micro-grafting shoot tip culture of Citrus on three trifoliate rootstocks. Scientia Hort., 23: 255-259.

EL-Bahrany A.M. (2001). Effect of phytohormones on in vitro shoot multiplication and rooting of lime (Citrus aurantifolia( Christm). Swing.). Scientia Horticultura, 95(4): 285-295.

Ghorbel, R., L. Navarro and N. Duran-Vila.(1998). Morphogenesis and regeneration of whole plants of grapefruit ( Citrus paradisi), sour orange (C. aurantium) and alemow (C. macrophylla). J. Hort. Sci. Biotechnol., 73: 323-327.

Goh, C.J., E.G. Sim, L.C. Morales and C.S. Loh.(1995). Plantlet regeneration through different morphogenetic pathways in pommel tissue culture. Plant Cell Tiss. Orgen Cult., 43:301-303. 
Gomez, K.A. and A.A. Gomez.(1984). Statistical procedures for the agriculture research. John Waley \& Sons, Int. Rice Res. Inst. Book 2Ed.

Guindy, L.F.; S.E. Salem and S.S. Moustafa.(1995). Effect of bud -forcing methods on bud take and scion growth of Citrus grown in containers. Bull. Fac. Agric. Cairo Univ., 46(2): 243-52

Hartmann, H.T.; D.E. Kester and F.T. Davies.(1990).Plant propagation: Principles and practices5th Edition Prentice-Hall, Englewood Cliffs, NJ.

Kaya, B. and H. Gubbuc.(2001). Investigation on the propagation of some Citrus rootstock byTissue culture. Ziraat Fakultesi Dergiste, Akdeniz Universitesi, 14 (2): 69-76.

Ke, S.; Q. Cai and R.M. Skirvin.(1993). Micrografting speeds growth and fruiting of protoplasts -derived clones of kiwifruit (Actinidia deliciosa). J. Hort. Sci., 68 : 837-840.

Krishan-Kumar; S.A. Dhett and I.M. Gill.(2001). In vitro plant regeneration in sweet orange. Indian Journal of Horticulture, 58 (3): 208-211.

Lineberger, D.(2006). The many dimensions of plant tissue culture research. Webmaster of Aggie. Horticulture (http//aggie horticulture tamu. edu./tisscult/patiissue/pltissue.html).

Lukman, D.R.; R. Janor and P. Villemur.(1990). Shoot apices culture of Troyer citrange. Indonesian Journal of Tropical Agric., 1 (2): $72-74$.

Maggon, R. and D.B. Singh.(1995). Promotion of adventitious bud regeneration by $A B A$ in combination with BAP in epycotyl and hypocotyl explants of sweet orange ( Citrus sinensis L. Osbeck). Sci. Hort., 63: 123-128.

Mas, O.; N.D. Valle and M. Ramos.(1994). In vitro propagation of citron. The International Citrus Congress, Acireale, Italy, 8-13 March, 1994 Pp.318-320.

Mas Camacho, D.; A. Rios Cruz; B. Morales Dominguez; M. Mirable Maranjo; A. Campos Roque and M. Gonzalez Montenegro.(1991). Methodology for induction of in vitro Propagated Citrus material. Centro Agricola, 18(3): 75-78 (Cuba).

Matsumoto, K.; K. Okuno; Y. Yonetsu and S. Hisajima.(2000). Application of in vitro plant of Citrus to environmental preservation (part 2) optimization of micro-propagation of Suntara orange by cost simulation. Journal of Society of High Technology of Agric, 12 (1): $30-$ 37.

Ministry of Agriculture, Research Institute of Horticulture (2007). Plantation and production of Citrus trees in Egypt.

Misra, K.K., R. Singh and H.R. Jaiswal. (1995). Effect of rootstocks on grown, yield and survival of lemon. Indian J. Hort., 52(3):186-191.

Moreira-Dias, J.M.; R.V. Molina; Y. Bordon; J.L. Guardiola and A. Gachia.(2000). Direct and Indirect shoot regeneration pathways in epicotyl cuttings of Troyer citrange differ in Hormone requirements and in their response to light. Ann. Bot. J., 85 (1): 103-110.

Murashige, T. and F. Skoog.(1962). A revised medium for rapid growth and bioassay with Tobacco tissue cultures. Physiol. Plant, 15 : 437-497. 
Murashige, T.; W.P. Bitters; T.S. Rangan; E.M. Nauer; C.N. Roistacher and P.B. Holliday.(1972).A technique of shoot apex grafting and its utilization towards recovering virus-free Citrus clones. Hort. Science, 7: 118-119.

Navarro, L.; C.N. Raistacher and T. Murashigo.(1975). Improvement of shoot tip grafting in Vitro for virus free Citrus. J. Amer. Hort. Sci., 10(5): 471479.

Obeidy, A.A. and L.A.M. Smith.(1991).A versatile new tactic for fruit tree micro-grafting. Hort. Technology, 1 (1): 91-95.

Ochatt, S.J. and D. De-Azkue.(1986). Callus proliferation and plant recovery with oxalis erosa knuth shoot tip cultures. J. Plant. Physiol., 117: 143146.

Parthasarathy, V.A. and V. Nagaraju. (1995). Effect of NAA and malt extract on in vitro growth of excited embryos of citrus rootstocks. International Journal of Tropical Agric. 19 (5): 114-119.

Pasqual, M. and A. Ando. (1990). Micro-propagation of trifoliate orange by lateral buds in vitro culture. Empersa Catarinense de Pesquise of Agric., 24 (2): 217-219.

Perez-Molpha; E. Balch and N.O. Ochoa-Alejo. (1997). In vitro plant regeneration of Mexican Lime and mandarin by direct organogensis. HortScience, 32 (2): 931-934.

Pontikis, C.A. and E. Sapoutzaki. (1985). Effect of phloroglucinol on successful propagation in vitro of Troyer citrange. Plant Propagator Journal, 30 (4): 108-111.

Ramsunder, V.; S. Sathlomorthy and S. Thamburaj. (1998). Rapid plant regeneration from Callus culture of acid lime (C. aurantifolia). South Indian Hor. Journal, 46 (3): 196-197.

Rouse, R. F. (1988). Bud- Foreing method affects bud break and scion growth of Citrus grown in containers. J. RioGrande vally Hort., 41: 6973.

Sadlak, J.; F. Paprstein; A. Bilavcik and J. Zamecnik. (2006). Proliferation and cold hardening of In vitro grown apple shoot tip. Acta Horticulturae, 1: 467-470.

Samaan, L.G.; M.S.S. El-Boray; M.F.M. Mostafa and O.A.). EL-Sawwah. (2000). Early diagnosis of compatibility degree in Washington navel orange graft combinations. J.Agric.Sci.Mansoura Univ.,25 (5): 2839 2854.

Sim, G.F., J.C. Goh and S.C. Loh. (1989). Micro-propagation of Citrus mitis Blanco- multiple bud formation from shoot and root explants in the presence of 6-benzylaminopurine. Plant Sci., 59: 203-210.

Sing, I.P. (2002). Micro-propagation in Citrus - areview. Agricultural Review, 23(1): 1-13.

Singha, S. (1982). Influence of agar concentration on in vitro shoot proliferation of Mallus spp 'Almey' and Pyrus communis 'Seckel'. J. Amer. Soc. Hort. Sci., 107: 657-660. 
Singha, S.; E.C. Townsend and G.I. Oberly.(1985).Mineral nutrient status of crabapple and pear shoots cultured in vitro on varying concentration of three commercial agars. J. Amer. Soc. Hort. Sci., 110: 406-411.

Singh, S.; B.K. Ray; S. Bhattacharyya and P.C. Deka.(2008). In vitro propagation of $\mathrm{C}$. reticulate and $\mathrm{C}$. lime. Journal of Interacademicia, 3 (2): 140-145.

Singh, S.; B.K. Ray; S. Bhattacharyga and P.C. Deka.(1995).In vitro propagation of Citrus Reticulate Blanco and Citrus lemon Burg. J. Hort. Sci., 29 (3): 214-216.

Stoltz, L.P.(1971). Agar restriction oh the growth of excised mature iris embryos. J. Amer. Soc.Hort. Sci., 96: 681-684.

Tusa, N.; L. Radogna; M. Davino and R. La Rosa.(1988).Micro-grafting technology for Recovering three virus/affected "Femminello" lemon clones. Acta Hort., 227: 104-106.

Vijayakumari, N. and S. Singh.(2003).Standardization of micro-budding technique in Citrus.Indian J. Hort., 60 (2): 127-13o.

Wardle, K.; D. Dalson; I. Simpkins and K. C. Skort.(1983). Annals of Botany, 5(2): 261-264.

Williamson, J.G.; W.S. castle and K.E.Koch.(1992). Growth and C14photosynthate allocation In Citrus nursery tree subjected to one of three bud-forcing method. J. Amer. Soc. Hort. Sci., 7 (1): 37-40.

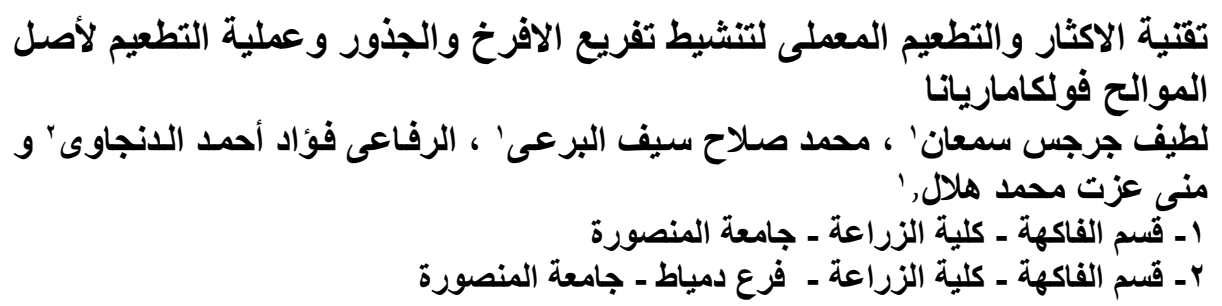

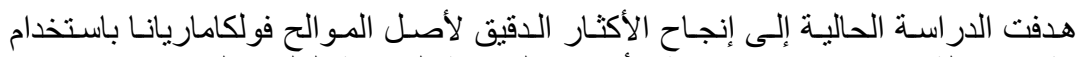

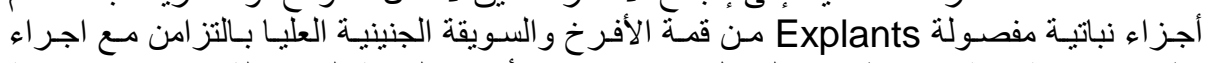

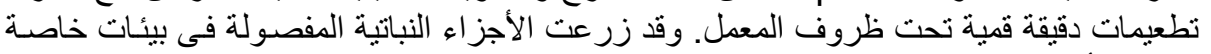

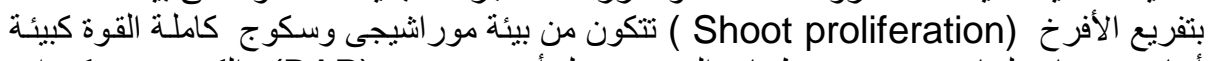

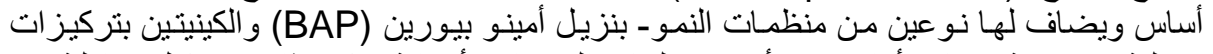

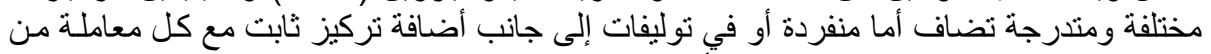

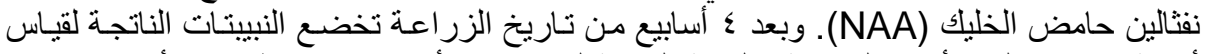

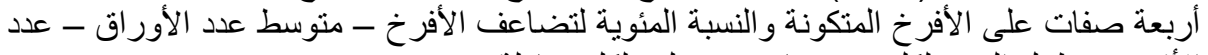

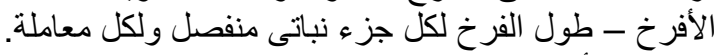

أجريت دراسة على تفريع الجذور العرضية (Root proliferation ) على التهلية الأجزاء

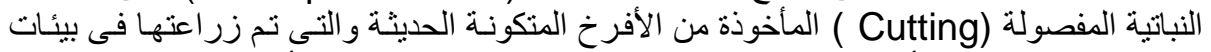

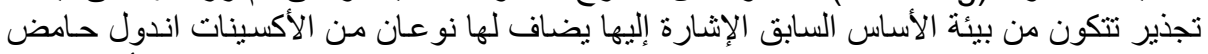

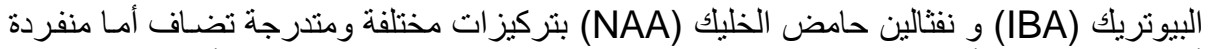

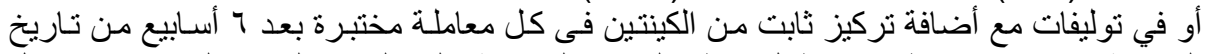

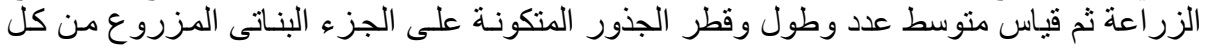


معاملة. أجريت أيضا عمليات تركيب تطعيمية لصنفى البرتقال أبو سره و الفلنشيا كطعوم على أصل

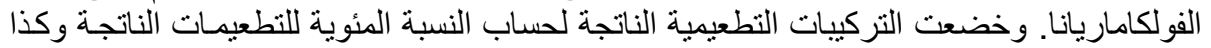

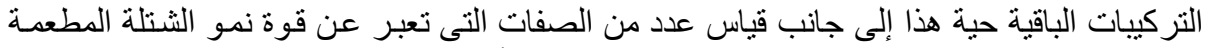

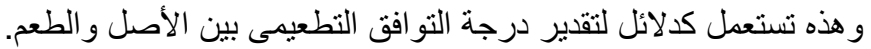

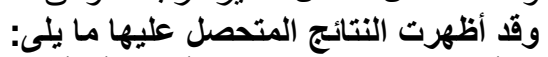

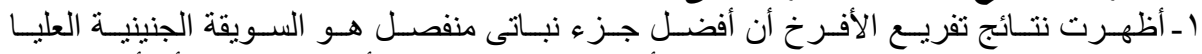

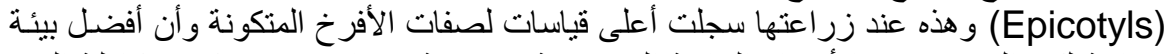

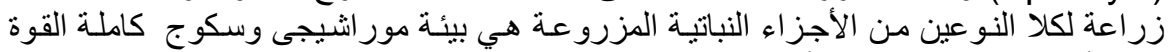

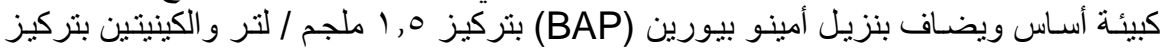

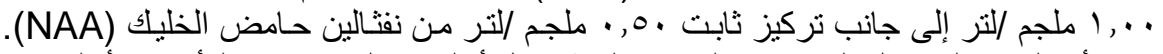

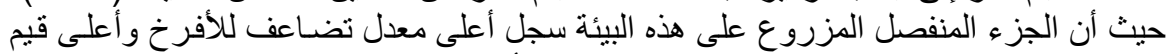

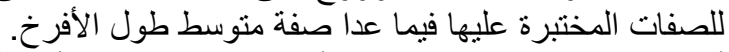

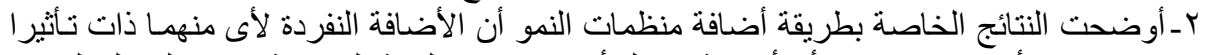

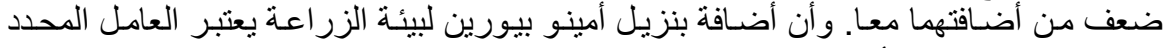

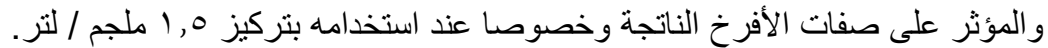

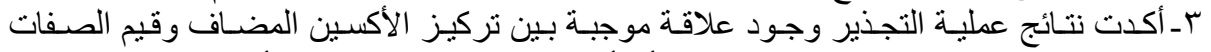

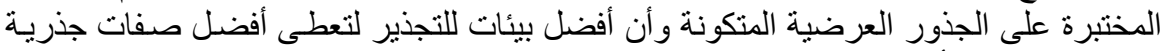

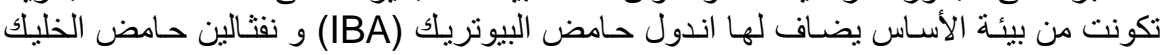

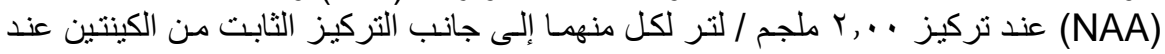

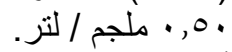
ع ـ أوضح تقدير النسبة المئوية للتطعيمات الناجحة عند عمر شهر في المعمل وكذا الثتلات المطعدة

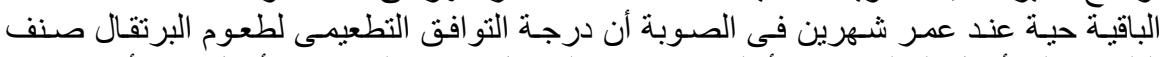

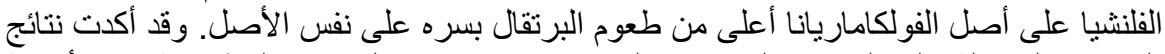

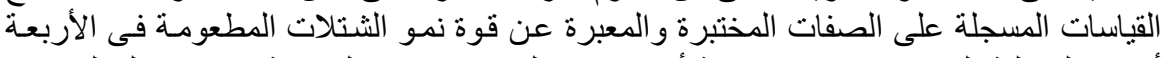

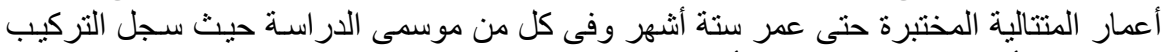

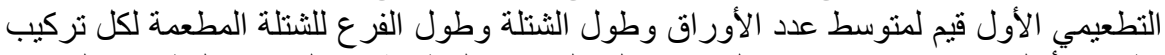
تطعيمي أعلى مستوى من قيم هذه الصفات على الثتلات المطعمة من التركيب التطعيمي الثاني. 